\title{
Aeromonas veronii and Plesiomonas shigelloides (Gammaproteobacteria) isolated from Glossogobius aureus (Gobiidae) in Lake Sampaloc, Laguna, Philippines
}

\author{
Janelle Laura J. Gacad ${ }^{1, *}$ and Jonathan Carlo A. Briones ${ }^{1,2,3,}$
}

\begin{abstract}
Bacterial infections are high-risk factors in fisheries, with reports of high mortality among diseased fish stocks posing a threat to both capture and aquaculture fisheries in inland waters. Diseases-causing bacteria in fishes may lead to decreased yield and economic loss to fishers, whose livelihood primarily depends on landed catch. Lake fisheries are most affected by such disruptive changes because of limitations in water turnover aggravated by wastewater inputs. In this study, we isolated and characterized gut bacteria from landed catch of the gobiid Glossogobius aureus from Lake Sampaloc, a small but commercially important aquaculture area in Luzon. Isolated axenic gut bacteria were identified through Gram stain reaction, microscopy, API biochemical tests, and 16s rRNA gene sequencing. From these, we identified two species with known fish pathogenicity, namely Aeromonas veronii and Plesiomonas shigelloides which are known to thrive in disrupted and nutrient-rich habitats and cause visible damage to fish health. Interestingly, our samples have shown no such visible signs of the disease. It is therefore important for future researches to determine what conservation and management practices in small inland waters like lakes will limit potential environmental stressors that may trigger susceptibility of both capture and farmed fish species to infection. Ultimately, rehabilitation of inland water aquaculture areas such as Lake Sampaloc is essential not only to fish conservation but also to public health and local food security.
\end{abstract}

Keywords: aquaculture, bacteria, goby, lake fisheries

\section{Introduction}

Bacterial diseases are among the major concerns in fisheries. Disease outbreaks result in high mortality and significant economic loss because of decreased fish production and yield (FAO 1986). Moreover, this spills over to the local habitat and results in reduced aquatic biodiversity and exposure of humans to potentially opportunistic pathogens (Austin \& Austin 2007; Zhang et al. 2016). Fisheries within inland water bodies, such as lakes, are particularly at risk because they retain water longer (Cusack \& Cone 1986; Busch et al. 2003; Pylkkö et al. 2006).

For instance, many aquaculture lakes in the Asia-Pacific

${ }^{1}$ The Graduate School, ${ }^{2}$ Department of Biological Sciences of the
College of Science, and ${ }^{3}$ Research Center for the Natural and Applied
Sciences, University of Santo Tomas, Manila, Philippines
*Corresponding email: janellelauragacad@gmail.com
Date Submitted: 30 July 2020
Date Accepted: 30 August 2020

(C) Association of Systematic Biologists of the Philippines region suffered major disease outbreaks in the 1980s. Countries with thriving inland fisheries, such as Myanmar, Indonesia, Laos, Malaysia, Papua New Guinea, and Thailand deal with similar concerns of increased infection rates in fisheries related to deteriorating water quality (Tonguthia 1985). In the Philippines, multiple reports of fish mortality due to lesions and necrotic ulcers were observed in various fish species in Laguna de Bay (Llobrera \& Gacutan 1987). These were linked to the aquaculture industry where mismanagement often increased the susceptibility of fish to bacterial infections and parasitism (Olofintoye 2006).

The most widespread freshwater teleosts are gobies (Gobiidae), which rank second to cyprinids (Cypriniidae) in global diversity (Marsden et al. 1996). Freshwater gobies are considered economically important because they are an alternative food source for humans (Crane et al. 2015). Glossogobius aureus Akihito \& Meguro is a small but hardy freshwater gobiid known for its high adaptability and survivability under extreme conditions.

In this study, we focused on the isolation of gut bacteria from Glossogobius aureus collected from Lake Sampaloc in San 
Pablo, Laguna. Due to multiple threats to its biodiversity, the Global Nature Fund called Lake Sampaloc the "Threatened Lake of the Year" in 2014. As with other inland water bodies near urbanized areas, it has been subjected to many challenges - arguably more man-made than natural. It is only fitting that initiatives to restore inland fisheries in Lake Sampaloc must come from human intervention.

\section{Methods}

\section{Details of site and fish sampled}

Lake Sampaloc $\left(14.079^{\circ} \mathrm{N}, 121.33^{\circ} \mathrm{E}\right)$ is one of the seven crater lakes located in San Pablo City, Laguna, Philippines (Fig. 1a). It is an inactive volcanic maar with a maximum width of $1.2 \mathrm{~km}$, a surface area of $1.04 \mathrm{~km}^{2}$, an average depth of $10 \mathrm{~m}$ in most areas, and a maximum depth of $27 \mathrm{~m}$ (LLDA 2005). Common fish catch in the lake include tilapia, catfish, and gobiids (Briones et al. 2016).

\section{Fish gut preparation and bacteria isolation}

In June 2017, we sampled 10 specimens of Glossogobius aureus (Fig. 1b) averaging $12.8 \pm 0.5 \mathrm{~cm} \mathrm{TL}$ and $14.1 \pm 1.1 \mathrm{~g}$ in weight. The average size of this species is $12.0 \mathrm{~cm}$ (Allen 1989). These were processed within $24 \mathrm{~h}$ after collection. Each fish gut and its contents were washed with Sterile Normal Saline Solution (SNSS) and pooled in bulk. A $1 \mathrm{~g}$ portion was then homogenized with $9 \mathrm{~mL}$ SNSS to remove contaminants not associated with the gut, with the resulting suspension serially diluted $\left(10^{-1}\right.$ to $\left.10^{-5}\right)$ also with SNSS.

One-mL aliquots of each dilution level were pour-plated in duplicate plates of Trypticase Soy Agar (TSA). The plates were incubated at room temperature $\left(20-25^{\circ} \mathrm{C}\right)$ for $24 \mathrm{~h}$ (Llobrera \& Gacutan 1987; Zepeda-Velázquez et al. 2017). Colonies with distinctive morphology and coloration were selected and the 10 isolates thereof were eventually brought into pure culture for characterization and identification. The isolates were subcultured and purified twice using Multiple Interrupted Streaking (MIS) in TSA. All isolates obtained in pure culture were maintained in tubes of half-strength Tryptic Soy Broth (TSB) and stored under refrigerated conditions until further use.

\section{Bacteria characterization and identification}

Preliminary cultural characterization of bacterial isolates was based on colony morphology, Gram stain reaction, and cell shape and arrangement. The isolates were also grown on other agar media including Thiosulfate-Citrate Bile Salt-Sucrose (TCBS), which is a differential and selective medium. Phenotypic identification also focused on biochemical parameters including oxidase test, Sulfur-Indole-Motility (SIM)

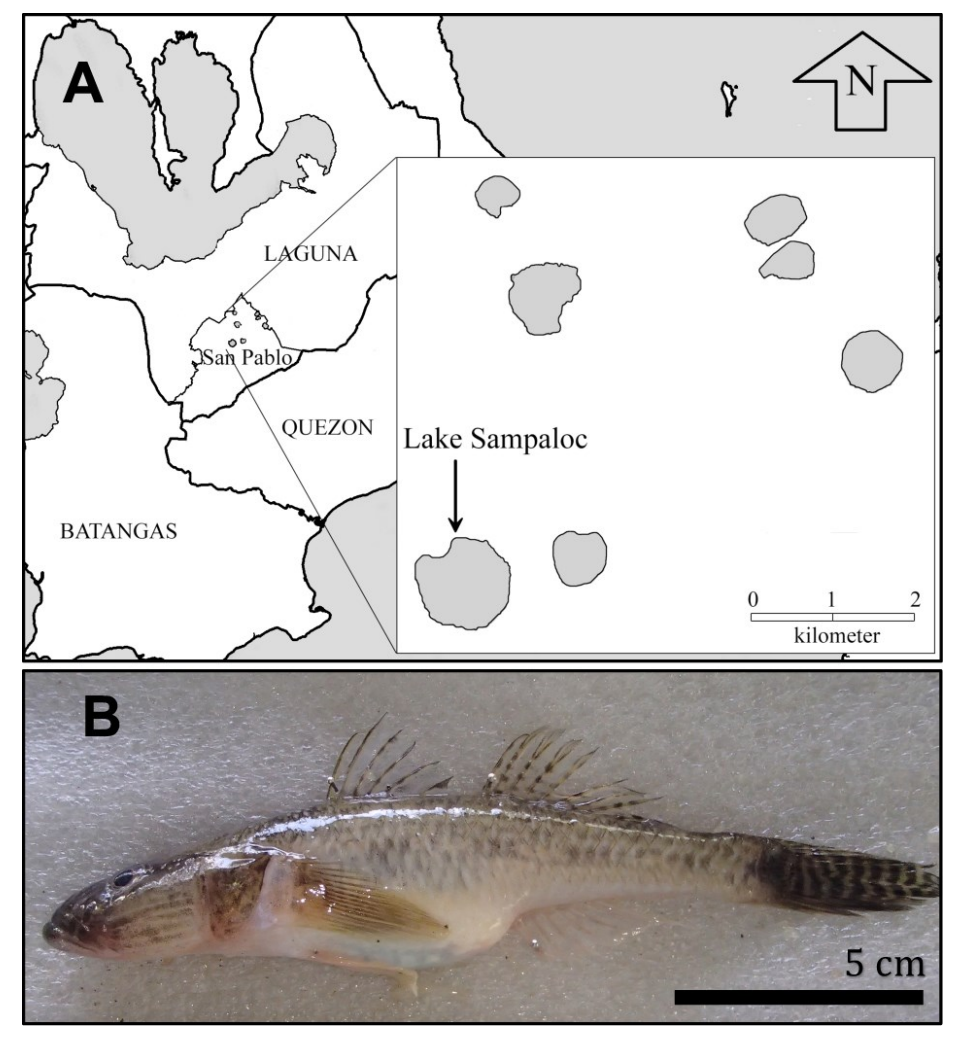

Figure 1. Details site and fish sampled of the sampling site. (A) map of Lake Sampaloc in the city of San Pablo, Laguna in the south of Luzon Island, and (B) photograph of Glossogobius aureus.

test and sugar fermentation using $\mathrm{O} / \mathrm{F}$ glucose. Results of the tests were used in combination with cultural characters for identification according to Holt et al. (1994). Analytical Profile Index (API) 20E rapid identification kits (bioMérieux) were also used for additional identification. Genotypic identification was done through $16 \mathrm{~S}$ rRNA gene sequencing. DNA from pure cultures was extracted following the protocol from Wizard Genomic DNA Purification Kit (Promega). The 16S rRNA genes of the isolated bacteria were amplified by PCR using a pair of $16 \mathrm{~S}$ rRNA universal primers designated as $27 \mathrm{~F}\left(5^{\prime}\right.$ - AGA GTT TGA TCM TGG CTC AG-3') for forward and 1492R (5'TAC GGY TAC CTT GTT ACG ACTT-3') for reverse (Alikunhi et al. 2016). The purified DNA product was sent to Macrogen (Seoul, Korea) for sequencing. The generated sequences were edited and assembled using Codon Code Aligner v.4.0. The assembled sequences were analyzed through BLAST Nucleotide search (BLASTn; http://blast.ncbi.nlm. nih.gov/Blast.cgi).

\section{Results and Discussion}

A total of 10 distinct colonies of gut bacteria were isolated from the gobiid fish samples. Phenotypic characterization of 
the isolates using the APIweb scanning software (Bio Mérieux, France) confirmed three probable genera of isolates (Plesiomonas sp., Aeromonas sp., and Vibrio sp.) through the use of Analytical Profile Index (API) rapid identification kits. Further analysis using 16s rRNA gene sequence identified by BLASTn yielded $97 \%$ homology to only two species: Aeromonas veronii strain NX16104 and Plesiomonas shigelloides strain JT-0601. Two isolates identified as $A$. veronii formed circular white or yellow colonies in TSA agar plates (Fig. 2A). These were coccobacilli to bacilli shaped and were motile (Figs. 2C, 2E). Tested colonies were facultative anaerobic, catalase- and oxidase-positive and were glucosefermenting (Figs. 2D, 2E). One isolate that was initially identified as Vibrio sp. in biochemical tests and API 20E (42.9\% ID) was later identified as A. veronii (97\% homology in 16s rRNA gene sequence). Eight isolates that were identified as $P$. shigelloides formed circular white colonies in TSA agar plates (Fig. 2F). These were also bacilli shaped and motile (Figs. 2H, 2J). These colonies were facultative anaerobic, oxidase-positive, and glucose fermenting (Fig. 2I). A comparison between the morphological and biochemical characteristics of $A$. veronii and $P$. shigelloides from this study and from previous studies is shown in Table 1.
To our knowledge, this study is among the few researches investigating bacterial pathogens of freshwater gobies in the Philippines. Among the few studies is that by Llobrera \& Gacutan (1987) which found Aeromonas sp. as the dominant isolate from gobies, mudfish, catfish, and crucian carp from Laguna de Bay, Philippines. In another study, Yambot (1998) documented the outbreaks of Aeromonas sp. infection in tilapia aquaculture farms in Luzon in the early 1990s. Finally, a research found Aeromonas spp. and Plesiomonas shigelloides in Nile tilapia and catfish in the Philippines and Thailand (Maluping et al. 2005).

The preliminary identification of Vibrio sp., which was later identified as Aeromonas veronii, can be attributed to the inherent limitations of some commercial identification kits such as API 20E, whose reliability is sometimes put in question when identifying some selected bacterial genera. Several studies have reported similar initial misidentification of Aeromonas as Vibrio (Abbott et al. 1994; Reina \& Lopez 1996; Altwegg 1999). Possible reasons for misidentification are: (1) the effect of salinity of the medium at the time of testing using the API 20E kit; (2) the variability of incubation time wherein API system requires $18-24 \mathrm{~h}$ or $48 \mathrm{~h}$ before reading. It is therefore recommended to continue monitoring the reactions for as long as 24 to $48 \mathrm{~h}$ even when the result has initially been

Table 1. Comparison of morphological and biochemical description of Plesiomonas shigelloides and Aeromonas veronii from Glossogobius aureus in Lake Sampaloc with other published studies.

\begin{tabular}{|c|c|c|c|c|c|c|}
\hline & \multicolumn{3}{|c|}{ Aeromonas veronii } & \multicolumn{3}{|c|}{ Plesiomonas shigelloides } \\
\hline & \multicolumn{3}{|c|}{$\begin{array}{l}\text { Previous studies } \\
\end{array}$} & \multirow[b]{2}{*}{ Present study } & \multicolumn{2}{|c|}{$\begin{array}{l}\text { Previous studies } \\
\end{array}$} \\
\hline & Present study & $\begin{array}{l}\text { Raj } \\
\text { et al. } \\
\text { (2019) }\end{array}$ & $\begin{array}{l}\text { Rahman et } \\
\text { al. (2004) }\end{array}$ & & $\begin{array}{l}\text { Behera et } \\
\text { al. (2018) }\end{array}$ & $\begin{array}{c}\text { Krovacek } \\
\text { et al. } \\
(2000)\end{array}$ \\
\hline \multicolumn{7}{|l|}{ Cell Morphology } \\
\hline shape & rods & rods & rods & short rods & rods & rods \\
\hline form & circular & NA & NA & circular & NA & NA \\
\hline texture & $\begin{array}{l}\text { translucent, } \\
\text { smooth, } \\
\text { white-yellow }\end{array}$ & $\begin{array}{l}\text { semi translucent, } \\
\text { yellowish }\end{array}$ & NA & $\begin{array}{l}\text { opaque-translucent, } \\
\text { white }\end{array}$ & NA & NA \\
\hline elevation & raised & NA & NA & flat & NA & NA \\
\hline margin & entire & NA & NA & entire & NA & NA \\
\hline \multicolumn{7}{|l|}{ Tests } \\
\hline Gram Reaction & $\mathrm{g}(-)$ & $\mathrm{g}(-)$ & $\mathrm{g}(-)$ & $\mathrm{g}(-)$ & $\mathrm{g}(-)$ & $\mathrm{g}(-)$ \\
\hline Catalase & $(+)$ & $(-)$ & $(+)$ & $(+)$ & NA & NA \\
\hline Oxidase & $(+)$ & $(+)$ & $(+)$ & $(+)$ & $(+)$ & $(+)$ \\
\hline Indole & $(+)$ & $(+)$ & NA & $(+)$ & $(+)$ & $(+)$ \\
\hline $\mathrm{O} / \mathrm{F}$ glucose & fermentative & fermentative & NA & oxidative & NA & NA \\
\hline H2S Production & $(-)$ & NA & $(+)$ & $(-)$ & $(+)$ & $(-)$ \\
\hline Motil & $(+)$ & $(+)$ & $(+)$ & $(+)$ & $(+)$ & $(+)$ \\
\hline MAC & $(+)$ & NA & NA & $(+)$ & NA & NA \\
\hline TCBS & yellow colonies & NA & NA & no growth & NA & NA \\
\hline
\end{tabular}




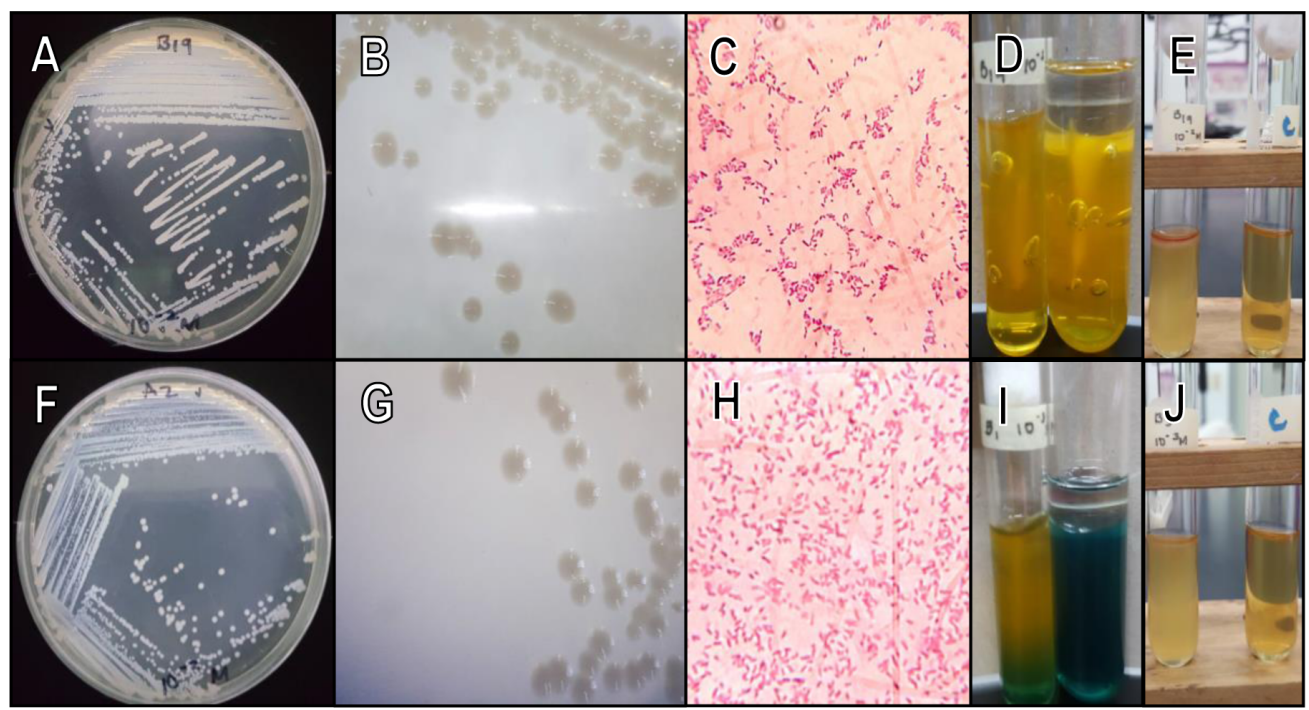

Figure 2. Photographs of morphology and biochemical tests for the two identified gut bacteria isolated from Glossogobius aureus from Lake Sampaloc, Laguna. Aeromonas veronii (A) growth in Trypticase Soy Agar; (B) colony features; (C) Gram-negative short bacilli; (D) growth in O/F Glucose and (E) Sulfur Indole Motility broth. Plesiomonas shigelloides (F) growth in Trypticase Soy Agar; (G) colony features; (H) Gramnegative short bacilli; (I) growth in O/F Glucose and (J) Sulfur Indole Motility broth.

interpreted after a few hours of incubation (Park et al. 2003).

The microorganisms observed in this study are associated with diseases resulting to fish mortalities in freshwater lakes, as well as some cases of potential risks to humans. Representatives of these two genera are considered the most prevalent bacteria in aquatic environments (Galindo \& Chopra 2007). Both $A$. veronii and $P$. shigelloides are ubiquitous and opportunistic pathogens which only infect fishes with low resistance, possibly exacerbated under drastic environmental changes, improper management, and parasitic infections (Dias et al. 2016). Common diseases caused by Aeromonas in fish are bacterial septicemia, ulcerations, hemorrhagic focus and epizootic ulcerative syndrome, which can lead to death within a week (Rahman et al. 2011). Common Aeromonas species that can be found in freshwater fish are A caviae Popoff, $A$. hydrophila (Chester) Stanier, $A$. jandaei Carnahan et al. and $A$. sobria (Austin \& Austin 2007).

P. shigelloides may cause protruded anus and hemorrhage around the vent that lead to septicemia in fishes (Cruz et al. 1986). There is also a growing awareness that some bacterial pathogens, including representatives of Aeromonas and Plesiomonas, may also infect humans who are infected not by fish consumption but through exposed wounds during leisure activities in lakes. Many reports claimed that humans exposed to bacterial pathogens have developed gastroenteritis, septicemia, meningitis, pneumonia, and surgical wound infection, primarily in immunocompromised patients (Hanson et al. 1977; Austin \& Austin 2007). It may be worthwhile to conduct molecular studies on isolates from fishes and human disease outbreaks to define epidemiological connections and identify zoonotic risks of disease-causing bacteria from fishes (Gauthier 2015).

In this study, the observed gut bacterial flora in gobies may be linked to its habitat where untreated sewage is drained, exerting adverse impacts on the lake's ecology (Dimzon et al. 2018). Bacteria present in the aquatic environment are known to influence the composition of fish gut flora (Cahil 1990). Past records of the deteriorating water quality of Lake Sampaloc (Jose 2005) were often anecdotally linked to multiple reports of epizootic mortality in the lake fish community. It will be interesting to determine how these various potential stressors can increase fish susceptibility to infection. The rehabilitation and appropriate management of inland waters such as Lake Sampaloc, which is a traditional aquaculture area, is essential not only to fish conservation but also to public health and local food security.

Meanwhile, among preventive or rehabilitative measures that local authorities and fishers may employ include lake cleanups, assessment of pollutants and their prevention and control, adoption of good aquaculture practices in fish farms and cages, and preventing the movement of infected stocks (Austin \& Austin 2007; Opiyo et al. 2018).

Our findings contribute to the body of knowledge for the conservation management of gobies in the Philippines. The gut bacteria of G. aureus in the Philippines is herein reported for the first time. Gut bacteria may pose a health hazard during the 
consumption of food gobies and therefore guided intervention must be prioritized by local government authorities and other relevant agencies. Thus, a follow up research is crucial to advancing our knowledge of these pathogens.

\section{Acknowledgements}

The authors are grateful to Dr. Irineo J. Dogma Jr. (Graduate School, University of Santo Tomas) for his invaluable insights, support and guidance for this study.

\section{Literature Cited}

Abbott, S.L., H. Serve \& J.M. Janda, 1994. Case of Aeromonas veronii (DNA group 10) bacteremia. Journal of Clinical Microbiology, 32(12): 3091-3093.

Alikunhi, N.M., Z.B. Batang, H.A. AlJahdali, M.A.M. Aziz \& A.M. Al-Suwailem, 2016. Culture dependent bacteria in commercial fishes: Qualitative assessment and molecular identification using 16s rRNA gene sequencing. Saudi Journal of Biological Sciences, 24(6): 1105-1116.

Allen, G.R., 1989. Freshwater Fishes of Australia. T.F.H.

Publications, Inc., Neptune City, New Jersey. 240 pp.

Altwegg, M., 1999. Aeromonas and Plesiomonas. In: Murray, P.R., E.J. Baron, M.A. Pfaller, F.C. Tenover, R.H. Yolken (Eds.), Manual of Clinical Microbiology, 7a ed. American Society for Microbiology. Washington, DC. 507-516.

Austin, B. \& D. Austin, 2007. Bacterial Fish Pathogens: Diseases of Farmed and Wild Fish. Praxis Publishing, Chichester, UK. 106-107 pp.

Behera, B. K., A.K. Bera, P. Paria, A. Das, P.K. Parida, S. Kumari, S. Bhowmick \& B.K. Das, 2018. Identification and pathogenicity of Plesiomonas shigelloides in Silver Carp. Aquaculture, 493: 314-318.

Briones, J.C.A., R.D.S. Papa, G.A. Cauyan, N. Mendoza \& N. Okuda, 2016. Fish diversity and trophic interactions in Lake Sampaloc (Luzon Is., Philippines). Tropical Ecology, 57: 567-581.

Busch S., I. Dalsgaard \& K. Buchmann, 2003. Concomitant exposure of rainbow trout fry to Gyrodactylus derjavini and Flavobacterium psychrophilum: effects on infection and mortality of host. Veterinary Parasitology, 117: 117-122.

Cahill, M.M., 1990. Bacterial flora of fishes: A review. Microbial Ecology, 19: 21-41.

Camacho, A.S. \& N. Macalincag-Lagua, 1988. The Philippine Aquaculture Industry. In: J.V. Juario \& L.V. Benitez (Eds.), Perspectives in Aquaculture Development in Southeast Asia and Japan: Contributions of the SEAFDEC Aquaculture Department. Proceedings of the Seminar on
Aquaculture Development in Southeast Asia, 8-12 September 1987, Iloilo City, Philippines. Tigbauan, Iloilo, Philippines: SEAFDEC, Aquaculture Department. 91-116.

Crane, D.P., J.M. Farrell, D.W. Einhouse, J.R. Lantry \& J.L. Markham, 2015. Trends in body composition of native piscivores following invasion of Lake Erie and Ontario by the round goby. Freshwater Biology, 60: 111-124.

Cruz, J.M., A. Saraiva, J.C. Eiras, R. Branco \& J.C. Sousa, 1986. An outbreak of Plesiomonas shigelloides in farmed rainbow trout, Salmo gairdneri Richardson, in Portugal. Bulletin of the European Association of Fish Pathologists, 6: 20-22.

Cusack, R. \& D.K. Cone, 1986. A review of parasites as vectors of viral and bacterial diseases of fish. Journal of Fish Diseases, 9: 169-171.

Dias, M.K.R., L.S. Sampaio, A.A. Proietti-Junior, E.T.O. Yoshioka, D.P. Rodriques, A.F.R. Rodriguez, R.A. Ribeiro, F.S.E.D.V. Faria, R.O.A. Ozório \& M. Tavares-Dias, 2016. Lethal dose and clinical signs of Aeromonas hydrophila in Arapaima gigas (Arapaimidae), the giant fish from Amazon. Veterinary Microbiology, 188: 12-15.

Dimzon, I.K.D., A.S. Morata, J. Müller, R.K. Yanela, S. Lebertz, H. Weil, T.R. Perez, J. Müller, F.M. Dayrit \& T.P. Knepper, 2018. Trace organic chemical pollutants from the lake waters of San Pablo City, Philippines by targeted and non-targeted analysis. Science of the Total Environment, 639: 588-595.

Galindo, C. \& A. Chopra, 2007. Aeromonas and Plesiomonas species. In: Doyle, M. \& L. Beuchat (eds.), Food Microbiology: Fundamentals and Frontiers, Third Edition. ASM Press, Washington, D.C. 381-400.

Gauthier, D.T., 2015. Bacterial zoonoses of fishes: A review and appraisal of evidence for linkages between fish and human infections. The Veterinary Journal, 203(1): 27-35.

Global Nature Fund, 2014. Intensive fish farming threatens Philippine crater lake - Lake Sampaloc is "Threatened Lake of the Year 2014". Press release of Global Nature Fund for World Wetlands Day on 2nd February 2014. pp. 1-2.

Hanson, P.G., J. Standridge, F. Jarrett \& D.G. Maki, 1977. Freshwater wound infection due to Aeromonas hydrophila. The Journal of the American Medical Association, 238(10): 1053-1054.

Holt, J.G., R.N. Krieg, P.H.A. Sneath, J.T. Staley \& S.T. Williams, 1994. Bergey's Manual of Determinative Bacteriology, 9th ed. Williams and Wilkins, Baltimore. 787 pp.

Jose, A., 2005. Sustaining the resource use and management of Sampaloc Lake, San Pablo City, Philippines: A potable source of water. In: LakeCon2003: Proceedings of the First 
National Congress on Philippine Lakes, Cuvin-Aralar, M.L. et al., (Eds.) SEARCA, Los Baños, Philippines.

Krovacek, K., L.M. Eriksson, C. Gonzales-Rey, J. Rosinsky \& I. Ciznar, 2000. Isolation, biochemical and serological characterisation of Plesiomonas shigelloides from freshwater in Northern Europe. Comparative Immunology, Microbiology \& Infectious Diseases, 23: 45-51.

Laguna Lake Development Authority (LLDA), 2005. Water Quality Report on Sampaloc Lake 1996-2005. Terminal Report of the LLDA Environmental Quality Management Division, Philippines.

Llobrera, A.T. \& R.Q. Gacutan, 1987. Aeromonas hyrophila associated with ulcerative disease epizootic in Laguna de Bay, Philippines. Aquaculture, 67: 273-278.

Maluping, R.P., C.R. Lavilla-Pitogo, A. DePaola, J.M. Janda, K. Krovacek \& C. Greko, 2015. Antimicrobial susceptibility of Aeromonas spp., Vibrio spp., and Plesiomonas shigelloides in the Philippines and Thailand. International Journal of Antimicrobial Agents, 25(4): 34850.

Marsden, J.E., P. Charlebois, K. Wolfe, D. Jude \& S. Rudnicka, 1996. The round goby (Neogobius melanostomus): A review of European and North American literature. Aquatic Ecology Technical Report 96/10. Illinois Natural History Survey, Zion, IL. pp. 6-60.

Olofintoye, L.K., 2006. Parasitofauna in some freshwater fish species in Ekiti State, Nigeria. Pakistan Journal of Nutrition, 5(4): 359-362.

Opiyo, M.A., E. Marijani, P. Muendo, R. Odede, W. Lesche \& H. Charo-Karisa, 2018. A review of aquaculture production and health management practices of farmed fish in Kenya. International Journal of Veterinary Science and Medicine, 6: 141-148.

Park, T.S., S.H. OH, E.Y. Lee, T.K. Lee, K.H. Park, M.J. Figueras \& C.L. Chang, 2003. Misidentification of Aeromonas veronii biovar. sobria as Vibrio alginolyticus by the Vitek system. Letters in Applied Microbiology, 37: 349-353.

Pylkkö P., L.R. Suomalainen, M. Tiirola, \& E. T. Valtonen, 2006. Evidence of enhanced bacterial invasion during Diplostomum spathaceum infection in European grayling, Thymallus thymallus (L.). Journal of Fish Diseases, 29: 6879.

Rahman, M.H., S. Suzuki \& K. Kawai, 2011. The effect of temperature on Aeromonas hydrophila infection in goldfish Carassius auratus. Journal of Applied Ichthyology, 17: 282 -285 .

Raj, N.S., T.R. Swaminathan, A. Dharmaratnam, S.A. Raja, D. Ramraj \& K.K. Lal, 2019. Aeromonas veronii caused bilateral exophthalmia and mass mortality in cultured Nile tilapia, Oreochromis niloticus (L.) in India. Aquaculture, 512: 734278.

Reina, J. \& A. Lopez, 1996. Gastroenteritis caused by Aeromonas trota in a child. Journal of Clinical Pathology, 49: 173-175.

Tonguthai, K., 1985. A preliminary account of ulcerative fish diseases in the Indo-Pacific region (A comprehensive study based on Thai experiences). National Inland Fisheries Institute, Bangkok, FAO/ TCP/ RAS/ 4508. 39 pp.

Yambot, A.V., 1998. Isolation of Aeromonas hydrophila from Oreochromis niloticus during fish disease outbreaks in the Philippines. Asian Fisheries Science, 10: 347-354.

Zepeda-Velázquez, A.P., V. Vega-Sánchez, C. Ortega-Santana, M. Rubio-Godoy, D.M.D. De Oca-Mira \& E. SorianoVargas, 2017. Pathogenicity of Mexican isolates of Aeromonas sp. in immersion experimentally infected rainbow trout (Oncorhynchus mykiss, Walbaum 1792). Acta Tropica, 169: 122-124.

Zhang, D., D. Xu \& C. Shoemaker, 2016. Experimental induction of motile Aeromonas septicemia in channel catfish (Ictalurus punctatus) by waterborne challenge with virulent Aeromonas hydrophila. Aquaculture Reports, 3: 18 -23 . 